\title{
Toxic metal levels in children residing in a smelting craft village in Vietnam: a pilot biomonitoring study
}

\author{
Alison P Sanders ${ }^{1 \dagger}$, Sloane K Miller ${ }^{1 \dagger}$, Viet Nguyen ${ }^{2}$, Jonathan B Kotch ${ }^{2}$ and Rebecca C Fry ${ }^{1,3,4^{*}}$
}

\begin{abstract}
Background: In Vietnam, environmental pollution caused by small-scale domestic smelting of automobile batteries into lead ingot is a growing concern. The village of Nghia Lo is a smelting craft village located roughly $25 \mathrm{~km}$ southeast of Hanoi in the Red River Delta. Despite the concern of toxic metal exposure in the village, biomonitoring among susceptible populations, such as children, has not been previously conducted. The aim of this study was to determine the body burden of toxic metals in children residing in a smelting craft village.

Methods: Twenty children from Nghia Lo, Vietnam, ages 18 months to four years were selected for capillary whole blood and toenail biomonitoring. Whole blood lead levels (BLLS) were measured using a portable lead analyzer, and toenail levels of arsenic, cadmium, chromium, lead, manganese, and mercury were analyzed with inductively coupled plasma-mass spectrometry.

Results: The findings show that all of the 20 children had detectable BLLs, and every child had levels that exceeded the Centers for Disease Control and Prevention guideline level of $5 \mu \mathrm{g} / \mathrm{dL}$. Eighty percent of tested subjects had BLLs higher than $10 \mu \mathrm{g} / \mathrm{dL}$. Five children (25\%) had BLLs greater than $45 \mu \mathrm{g} / \mathrm{dL}$, the level of recommended medical intervention. In addition to blood lead, all of the children had detectable levels of arsenic, cadmium, chromium, lead, manganese, and mercury in toenail samples. Notably, average toenail lead, manganese, and mercury levels were $157 \mu \mathrm{g} / \mathrm{g}, 7.41 \mu \mathrm{g} / \mathrm{g}$, and $2.63 \mu \mathrm{g} / \mathrm{g}$ respectively, well above levels previously reported in children. Significant Spearman's rank correlations showed that there were relationships between blood and toenail lead levels $(r=0.65, p<0.05)$, toenail levels of lead and cadmium $(r=0.66, p<0.05)$, and toenail levels of manganese and chromium $(r=0.72, p<0.001)$. Linear regression showed that reducing the distance to the nearest active smelter by half was associated with a $116 \%$ increase in BLL $(p<0.05)$.
\end{abstract}

Conclusions: The results suggest that children in battery recycling and smelting craft villages in Vietnam are co-exposed to toxic metals. There is an urgent need for mitigation to control metal exposure related to domestic smelting.

\section{Background}

Widespread environmental lead $(\mathrm{Pb})$ exposure contributes to adverse neurodevelopmental outcomes in children, which is associated with substantial economic losses [1,2]. The associated economic losses are estimated up to $\$ 319$

\footnotetext{
*Correspondence: rfry@unc.edu

${ }^{\dagger}$ Equal contributors

'Department of Environmental Sciences and Engineering, Gillings School of Global Public Health, University of North Carolina - Chapel Hill, Chapel Hill,

North Carolina, USA

${ }^{3}$ Curriculum in Toxicology, School of Medicine, University of North

Carolina - Chapel Hill, Chapel Hill, North Carolina, USA

Full list of author information is available at the end of the article
}

billion per year in the United States [1]. The detrimental neurodevelopmental effects of both prenatal and childhood lead exposure include decreased intelligence quotient (IQ) and cognitive function, diminished attention span, academic proficiency, fine-motor control, and visual-motor control [3,4]. Children are especially at risk for $\mathrm{Pb}$ exposure due to increased hand to mouth activity, increased exposure to soils and household dusts containing $\mathrm{Pb}$, and higher relative gastrointestinal absorption of $\mathrm{Pb}$ [5-7]. These factors can result in elevated blood lead levels (BLLs) in children [5,6] and a greater adverse effect on the developing nervous system [3]. Specifically, a

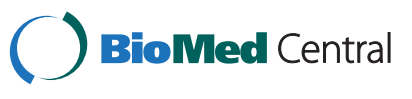


$10 \mu \mathrm{g} / \mathrm{dL}$ average increase in children's blood $\mathrm{Pb}$ concentration is associated with a decline in 1.9 to 3.2 IQ points [1].

$\mathrm{Pb}$ exposure often coincides with other toxic metal exposures due to co-contamination of air, soil, or water supplies by industrial activities [8-12]. However, there have been limited studies of the interactive effects of toxic metals resulting from co-exposure in humans. Coexposure to toxic metals is associated with adverse health outcomes including birth defects and various types of cancer $[10,11]$. In addition, toxic metal exposure in childhood has been reported to decrease neuropsychological function, IQ, and overall academic achievement [13-15]. Lending support, mixed exposure to metals such as arsenic (As), cadmium (Cd), mercury $(\mathrm{Hg})$, and $\mathrm{Pb}$ has been shown to have greater toxicological effects in animal studies than exposure to a single metal [16-20].

The Red River Delta of Vietnam is approximately $21,000 \mathrm{~km}^{2}$ and has a population of nearly 20 million [21]. Co-exposure to toxic metals has been previously documented in this region due to a variety of sources, including occupational exposures due to local craft villages [22,23] as well as naturally-occurring metals in drinking water [24-27]. A craft village is a community in which multiple households participate in the production of a particular good such as textiles, construction materials, recycled metal, paper, or plastic. The recycling of $\mathrm{Pb}$-acid batteries is a lucrative process for local communities; however, it can result in massive $\mathrm{Pb}$ toxicity $[28,29]$. BLLs in children living in battery recycling communities have been measured as high as $613 \mu \mathrm{g} / \mathrm{dL}$ [28]. The recommended blood advisory level in the United States is $5 \mu \mathrm{g} / \mathrm{dL}$ for children [30]. Of concern, there is a lack of information on the environmental and broader health impacts of craft villages, particularly with respect to mixed toxic metal exposure.

In this pilot study we set out to determine the body burden of blood $\mathrm{Pb}$ in children residing in a smelting craft village in Nghia Lo, Vietnam. We also characterized levels of other toxic metals including As, $\mathrm{Cd}$, chromium $(\mathrm{Cr})$, manganese $(\mathrm{Mn}), \mathrm{Hg}$, and $\mathrm{Pb}$ in toenail samples. This pilot study begins to characterize children's toxic metal exposure in smelting craft villages in Vietnam.

\section{Methods}

\section{Study population}

The Nghia Lo village, Vietnam was selected for study due to local $\mathrm{Pb}$ smelting practices and prior evidence of environmental metal contamination. Nghia Lo is a rural community located roughly $25 \mathrm{~km}$ southeast of Hanoi in the Commune of Chi Dao, Hung Yen Province. The village population includes 1,800 individuals and 533 total households. In 2011, there were 211 children under five years of age. This cross-sectional pilot study selected 20 children who lived in closest proximity to domestic $\mathrm{Pb}$ smelters and/or had parents whose work included grinding the plastic cases of automobile batteries. This study was reviewed and approved by the Institutional Review Boards at the University of North Carolina (\#11-1371) and the Institute of Child Health Research in Vietnam. Parents and legal guardians consented for all children participating in this study. Capillary whole blood and toenail samples for metal biomonitoring analysis were collected from all participants. Demographic information including child's age and sex were provided by the parents during an interview following the signing of the informed consent and preceding biological specimen collection. Families with children whose BLLs exceeded $45 \mu \mathrm{g} / \mathrm{dL}$ were offered chelation treatment at the project's expense.

\section{Distance to exposure}

A portable global positioning system (GPS) device was used to collect the geographic coordinates of participants' residences, smelters, plastic refineries, and local schools. GPS coordinates were visualized in ESRI ArcGIS $^{\mathrm{TM}}$ software Version 10.0 (Redlands, CA). Shapefiles of Vietnam were obtained from OpenStreetMap ${ }^{\circ}$ contributors (openstreetmap.org). Distance to the nearest active smelter was calculated for each child.

\section{Capillary whole blood collection and analysis}

Children's fingers were prepared with an alcohol wipe according to the Centers for Disease Control and Prevention (CDC) guidelines and samples were collected into capillary tubes following a finger prick. Capillary whole blood was collected into metals-free phlebotomy tubes by a registered medical doctor. Samples were immediately analyzed for $\mathrm{Pb}$ content using our portable LeadCare $^{\oplus}$ II Analyzer (Magellan Diagnostics, Billerica, MA). The LeadCare ${ }^{\oplus}$ II is the only CLIA-waived device available to test for $\mathrm{Pb}$ exposure at the point of care. The LeadCare ${ }^{\circledast}$ II is currently used in clinics across the United States including Departments of Public Health; Women, Infants and Children (WIC)s clinics; and Head Start Programs. The portable system provides rapid quantification of fresh whole blood $\mathrm{Pb}$ levels in a rural setting. Control spikes and capillary whole blood samples were processed according to the manufacturer's protocol. Detectable BLLs measured by the system ranged between 3.3 and $69 \mu \mathrm{g} / \mathrm{dL}$. Pb was the only metal measured in the children's capillary whole blood.

\section{Toenail collection and analysis}

Toenails were collected by a registered nurse using a clean nail clipper. Toenail clippings were transported to the United States and metals analyses were performed at 
RTI International, Research Triangle Park, North Carolina. Prior to chemical analysis, nails were stringently washed with double distilled water and acetone to remove debris and any external trace metals. The toenails were allowed to dry at room temperature overnight in a sterile hood. The cleaned toenail samples were stored at room temperature in $1.5 \mathrm{~mL}$ tubes until weighing and chemical analysis.

Toenail samples from 20 children were analyzed for six metals using inductively coupled plasma-mass spectrometry (ICP-MS). The metals included As, Cd, Cr, Pb, Mn, $\mathrm{Hg}$. The toenails were extracted using a modified version of Method 3050B (USEPA, 1996). Each sample was spiked with $10 \mu \mathrm{L}$ of $1000 \mathrm{ppm}$ gold stock solution in order to retain mercury for measurement. Next, $0.5 \mathrm{~mL}$ nitric acid $\left(\mathrm{HNO}_{3}\right), 0.1 \mathrm{~mL}$ hydrochloric acid $(\mathrm{HCl})$, and $1 \mathrm{~mL}$ deionized water were added to the samples. The samples were heated at $95^{\circ} \mathrm{C}$ loosely capped to allow reflux for one hour. The samples were cooled, $1 \mathrm{~mL}$ of $30 \%$ hydrogen peroxide was added, and the samples were heated at $95^{\circ} \mathrm{C}$ for $15 \mathrm{~min}$. The samples were cooled, $0.4 \mathrm{~mL}$ of $\mathrm{HCl}$ was added, and the samples were heated at $95^{\circ} \mathrm{C}$ for an additional $15 \mathrm{~min}$. The samples were brought to a final volume of $10 \mathrm{~mL}$ using deionized water and vortex mixed. Samples were analyzed using a Thermo X-Series II ICPMS equipped with a dual gas collision cell. The limit of detection (LOD) among toenail metals varied for each individual because the available mass differed by sample, and a higher sample mass resulted in a lower LOD.

\section{Statistical analysis}

Statistical analysis was conducted using SAS 9.3 (SAS Institute Inc., Cary, North Carolina). Descriptive statistics were calculated for 20 children who provided capillary whole blood and toenail samples. Three samples for which BLLs exceeded the maximum quantifiable level of the LeadCare $^{\oplus}$ II Analyzer of $69 \mu \mathrm{g} / \mathrm{dL}$ were excluded from further analysis with toenail metal levels or other covariates, including sex, age, and distance to the nearest active smelter. No toenail metal levels were below their respective LOD. Spearman's correlation coefficient estimates among metal pairs and corresponding p-values were calculated. Toenail and blood metal levels were natural-log transformed to address the non-normal distribution of metal concentrations. Nearest distance to an active smelter (km) was also natural-log transformed. Unadjusted linear regression was performed to test the association between each blood or toenail metal level and child's age (treated as a continuous variable), sex (classified as a dichotomous variable with female serving as the referent group), or distance to nearest active smelter (treated as a continuous variable). Beta estimates and 95\% confidence intervals are presented, with statistical significance defined at alpha less than 0.05 .

\section{Results and Discussion}

In this study, we investigated toxic metal exposure in blood and toenail samples collected from 20 children living in Nghia Lo village, Chi Dao Commune in Northern Vietnam. Nine plastic grinders and 18 smelters were located within three $\mathrm{km}(\sim 1.9$ miles) of the village, in close proximity to schools and residential buildings (Figure 1). A single smelter was inactive at the time of this study, while the remaining 17 represent small-scale facilities were involved in active $\mathrm{Pb}$ smelting.

\section{Children in Vietnam craft villages were exposed to toxic metals}

To assess children's metal exposure in the Nghia Lo community, we measured metal levels in toenail clippings and blood $\mathrm{Pb}$ levels from 20 children less than five years of age. The average child's age in this study was 2.9 years and ranged from 1.5 to 4.2 years. The sample population consisted of eleven females and nine males. The shortest recorded distance a child lived from an active smelter was $410 \mathrm{~m}$. The average distance from each child's residence to the nearest active smelter was $581 \pm$ 188 m. Study participants' characteristics are presented in Table 1.

Among 20 children in this pilot study, all had detectable BLLs which were above the CDC's $5 \mu \mathrm{g} / \mathrm{dL}$ reference level for children [30] (Figure 2). Three of the children had BLLs above the maximum detectable level $(69 \mu \mathrm{g} / \mathrm{dL})$ of the portable $\mathrm{Pb}$ analyzer. Five of the children (25\%) had BLLs above $45 \mu \mathrm{g} / \mathrm{dL}$, the level above which chelation therapy is recommended [31]. Descriptive statistics of BLLs are presented in Table 2 . The levels of quantifiable blood $\mathrm{Pb}$ ranged from $6.7 \mu \mathrm{g} / \mathrm{dL}$ to $62.3 \mu \mathrm{g} / \mathrm{dL}$ (Table 2). The geometric mean and $95^{\text {th }}$ percentile BLLs for individuals with detectable levels ( $\mathrm{n}=17$ ) was $17.3 \mu \mathrm{g} / \mathrm{dL}$ and $62.3 \mu \mathrm{g} / \mathrm{dL}$. The levels observed in the Nghia Lo children are well above the geometric mean and $95^{\text {th }}$ percentile reported in the Fourth Report on Human Exposure to Environmental Chemicals (NHANES IV) among children in the United States ages one to five $(\mathrm{n}=911)$ which were $1.77 \mu \mathrm{g} / \mathrm{dL}$ and $5.10 \mu \mathrm{g} / \mathrm{dL}$, respectively [32].

In addition to blood $\mathrm{Pb}$, we also measured toenail levels of toxic metals including As, $\mathrm{Cd}, \mathrm{Cr}, \mathrm{Pb}, \mathrm{Mn}$ and $\mathrm{Hg}$ (Table 2). Toenail levels of each metal were detected in every participant. Notably, average toenail levels of $\mathrm{Hg}, \mathrm{Pb}$, and $\mathrm{Mn}$ were $2.63 \mu \mathrm{g} / \mathrm{g}$ (maximum: $32.6 \mu \mathrm{g} / \mathrm{g}$ ), $157 \mu \mathrm{g} / \mathrm{g}$ (maximum: $1120 \mu \mathrm{g} / \mathrm{g}$ ), and 7.41 (maximum: $18.9 \mu \mathrm{g} / \mathrm{g})$. These levels of $\mathrm{Hg}, \mathrm{Pb}$, and $\mathrm{Mn}$ were substantially higher than levels observed in previous studies. For example, in a single previous study among Saudi children the average toenail $\mathrm{Hg}$ level was $0.185 \mu \mathrm{g} / \mathrm{g}$ [33]. Two previous studies among adult populations reported average $\mathrm{Hg}$ toenail levels of $0.212 \mu \mathrm{g} / \mathrm{g}$ 


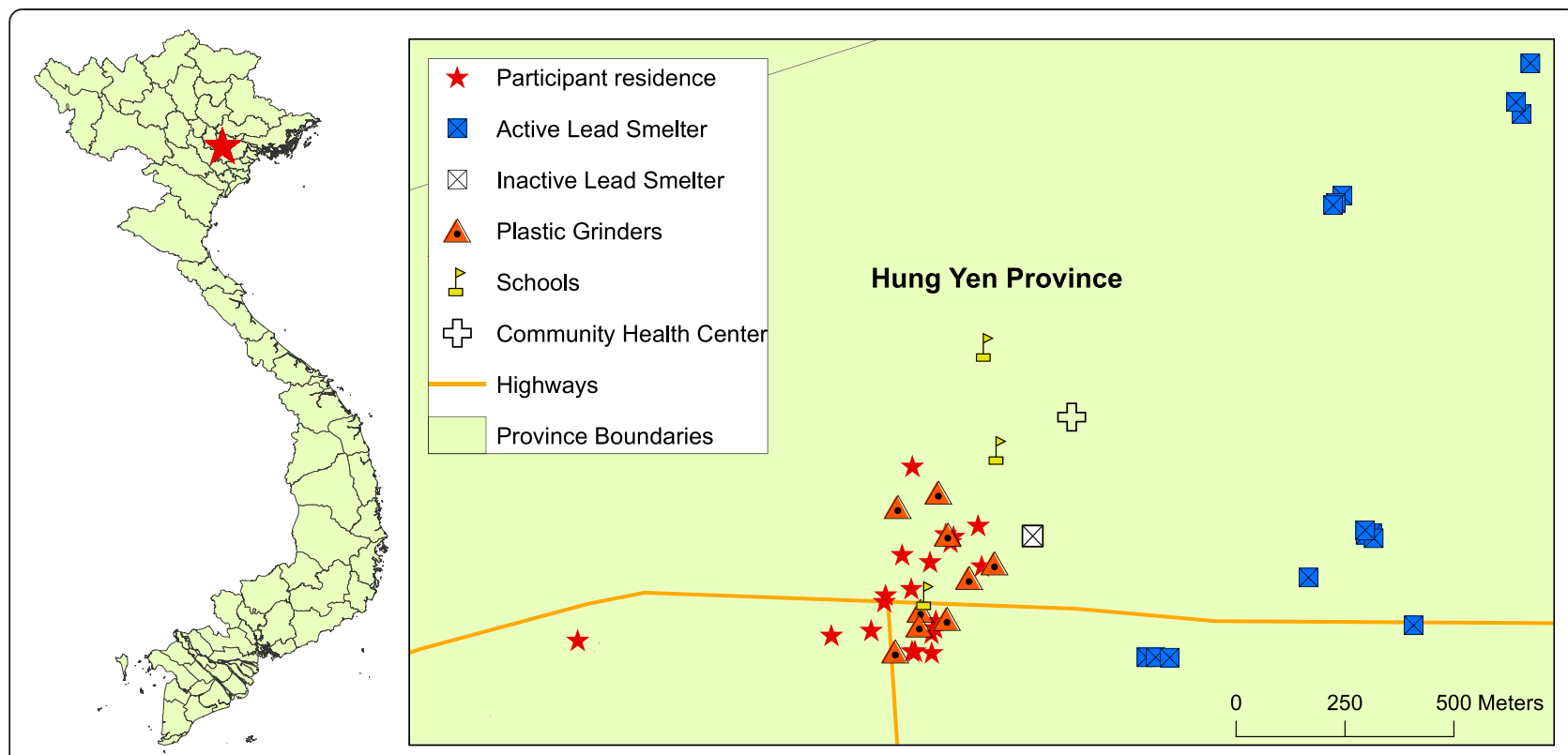

Figure 1 Children in Nghia Lo, Vietnam live in close proximity to lead smelters. Nine plastic grinders and 18 active or inactive smelters are located within three $\mathrm{km}$ of the Nghia Lo village.

(geometric mean) [34], and $0.25 \mu \mathrm{g} / \mathrm{g}$ [35]. In previous studies of children in Kenya, Germany, and the United States, average $\mathrm{Pb}$ toenail levels were $26.9 \mu \mathrm{g} / \mathrm{g}$ [36], 8.5 $\mu \mathrm{g} / \mathrm{g}$ [37], and $1.60 \mu \mathrm{g} / \mathrm{g}$ [38], respectively. In addition to levels of $\mathrm{Hg}$ and $\mathrm{Pb}$ that were higher than previously reported levels, the average toenail Mn level was considerably higher than a single previously reported level of $0.90 \mu \mathrm{g} / \mathrm{g}$ among children in the United States [38]. These findings highlight that markedly high levels of $\mathrm{Pb}$, $\mathrm{Hg}$, and $\mathrm{Mn}$ were detected in the toenails of the Nghia Lo children residing near craft smelting operations. Childhood exposure to $\mathrm{Pb}, \mathrm{Hg}$, or $\mathrm{Mn}$ is associated with diminished intellectual function [13-15,39,40].

Here we observed comparable or lower levels of As, $\mathrm{Cd}$, and $\mathrm{Cr}$ relative to previous studies of toenail metal levels. The average toenail levels of these three metals were $0.364 \mu \mathrm{g}-\mathrm{As} / \mathrm{g}, 0.286 \mu \mathrm{g}-\mathrm{Cd} / \mathrm{g}$, and $0.922 \mu \mathrm{g}-\mathrm{Cr} / \mathrm{g}$ (Table 2). The average toenail $\mathrm{Cr}$ level reported here was lower than the average $\mathrm{Cr}$ toenail level of $2.65 \mu \mathrm{g} / \mathrm{g}$ among children in the United States [38]. Likewise, the average $\mathrm{Cd}$ level was lower than the average $\mathrm{Cd}$ toenail levels reported in two studies of Kenyan and German

Table 1 Characteristics of the children $(n=20)$ living in Nghia Lo, Vietnam

\begin{tabular}{|c|c|}
\hline Child age (years) mean \pm SD (range) & $2.9 \pm 0.8(1.5-4.2)$ \\
\hline $\begin{array}{l}\text { Average distance to nearest } \\
\text { active } \mathrm{Pb} \text { smelter }(\mathrm{km}), \pm \mathrm{SD} \text { (range) }\end{array}$ & \\
\hline Females n (\%) & $11(55 \%)$ \\
\hline Males n (\%) & $9(45 \%)$ \\
\hline
\end{tabular}

children respectively, which were $0.790 \mu \mathrm{g} / \mathrm{g}$ [36] and $0.457 \mu \mathrm{g} / \mathrm{g}$ (geometric mean) [37]. Here the average toenail As level of $0.364 \mu \mathrm{g} / \mathrm{g}$ was comparable to the average levels of $0.14 \mu \mathrm{g} / \mathrm{g}$ and $0.49 \mu \mathrm{g} / \mathrm{g}$, reported in two studies of children in the United States and Australia $[38,41]$, but substantially lower than the average level of $5.9 \mu \mathrm{g} / \mathrm{g}$ reported among Bangladeshi children [42]. These data show that children are exposed to detectable levels of As, Cd, and Cr; with levels similar to, or lower than, previously reported toenail levels in children.

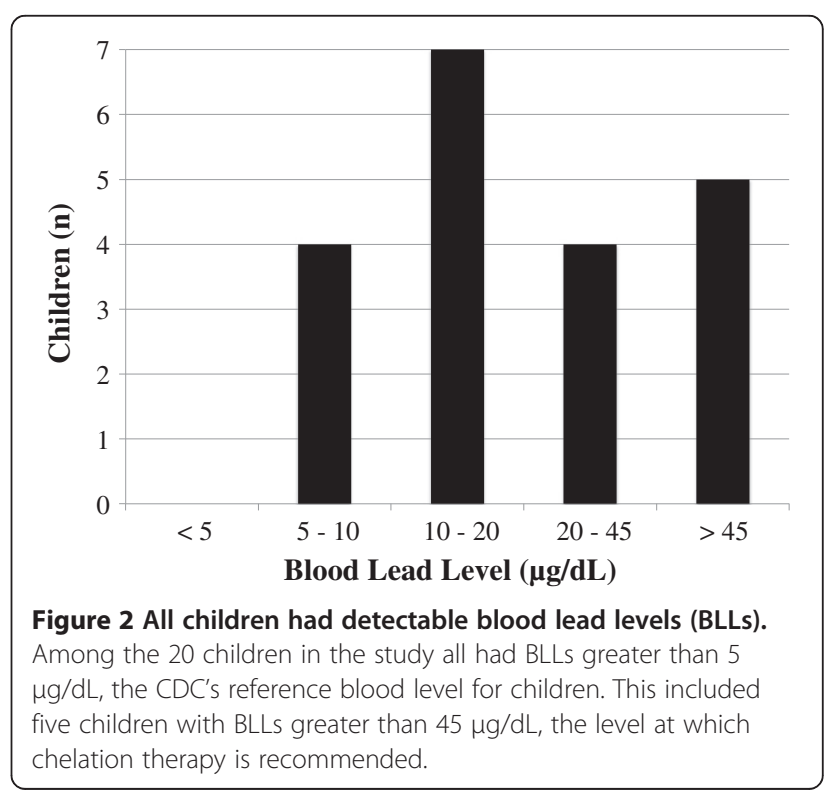


Table 2 Descriptive statistics of children's blood and toenail metal levels $(n=20)$

\begin{tabular}{|c|c|c|c|c|c|}
\hline Metal $^{a}$ & Mean $\pm \operatorname{stdev}(\mu \mathrm{g} / \mathrm{g})$ & Geometric mean $(\mu \mathrm{g} / \mathrm{g})$ & Minimum $(\mu \mathrm{g} / \mathrm{g})$ & $95^{\text {th }}$ percentile $(\mu \mathrm{g} / \mathrm{g})$ & Maximum $(\mu \mathrm{g} / \mathrm{g})$ \\
\hline $\mathrm{Pb}-\mathrm{B}^{\mathrm{b}}$ & $21.5 \pm 16.2$ & 17.3 & 6.7 & 62.3 & $62.3^{\mathrm{a}}$ \\
\hline As-N & $0.364 \pm 0.312$ & 0.289 & 0.109 & 1.09 & 1.46 \\
\hline $\mathrm{Cd}-\mathrm{N}$ & $0.286 \pm 0.326$ & 0.204 & 0.079 & 1.07 & 1.52 \\
\hline $\mathrm{Cr}-\mathrm{N}$ & $0.922 \pm 0.554$ & 0.809 & 0.321 & 2.09 & 2.87 \\
\hline $\mathrm{Pb}-\mathrm{N}$ & $157 \pm 315$ & 29.3 & 5.88 & 957 & 1120 \\
\hline Mn-N & $7.41 \pm 4.41$ & 6.17 & 2.34 & 15.6 & 18.9 \\
\hline $\mathrm{Hg}-\mathrm{N}$ & $2.63 \pm 7.07$ & 1.08 & 0.328 & 17.2 & 32.6 \\
\hline
\end{tabular}

${ }^{\mathrm{a}} \mathrm{B}$ denotes blood metal levels. $\mathrm{N}$ denotes toenail metal levels.

${ }^{\mathrm{b}} \mathrm{Blood} \mathrm{Pb}$ units are expressed in $\mu \mathrm{g} / \mathrm{dL}$. Three BLLs which exceeded the $69 \mu \mathrm{g} / \mathrm{dL}$ maximum quantifiable level were excluded from the calculated descriptive statistics.

Taken together, these findings suggest that children in battery recycling and smelting craft villages in Vietnam may significantly higher blood $\mathrm{Pb}$ and toenail $\mathrm{Pb}, \mathrm{Hg}$ and $\mathrm{Mn}$ levels compared to the other measured toxic metals and compared to the levels measured in other populations. The higher metal body burden potentially results from instances of co-exposure within the craft village. This is concerning as higher body burden of $\mathrm{Pb}$, $\mathrm{Hg}$, and $\mathrm{Mn}$ in children is associated with adverse neurodevelopmental outcomes $[39,40,43]$. In particular, coexposure to toxic metals has been demonstrated to have more detrimental health outcomes than single metal exposures in children $[13,44]$ and in numerous animal studies [16-20]. Subsequent neurodevelopmental health outcomes of multiple metal exposures in local craft villages should be prioritized in future studies.

It is clear that this pilot study has limited sample size. The cross-sectional design also has inherent weaknesses, as the blood and toenail measures characterize metal levels at a single point in childhood. Blood $\mathrm{Pb}$ levels reflect recent exposures on the order of days, whereas toenail levels can represent longer-term exposures on the order of months. It is noted that using nail as a biomarker is a better indicator for some metals (e.g., As, $\mathrm{Cd}, \mathrm{Cr}$, and $\mathrm{Hg}$ ) [45], whereas blood is the most appropriate biomarker for $\mathrm{Pb}$. In this study, the age range of 18 months to four years was selected to characterize a developmental time period of critical susceptibility. The elevated metal measures in nail biomarkers are particularly alarming indicators of early childhood metal exposure and additional studies should collect multiple samples throughout childhood.

Toxic metal levels in blood and toenails were correlated

To better understand co-exposure to toxic metals, we examined the pairwise relationships between metal levels measured in children's blood and toenail samples (Table 3). Spearman's rank correlation showed a statistically significant positive correlation $(\mathrm{p}<0.05 ; \mathrm{r}=0.65)$ between $\mathrm{Pb}$ levels measured in the blood $(\mu \mathrm{g} / \mathrm{dL})$ and $\mathrm{Pb}$ levels in toenail samples $(\mu \mathrm{g} / \mathrm{g})$ (Table 3$)$. No other relationships between blood $\mathrm{Pb}$ and toenail metal levels were statistically significant. These findings potentially indicate both chronic and acute $\mathrm{Pb}$ exposure as reflected by nail and blood levels, respectively [46]. Children may be exposed to $\mathrm{Pb}$ through a variety of smelting and nonsmelting related activities such as direct contact with smelting materials; contact with $\mathrm{Pb}$ residues remaining on parents' work clothing; or via contaminated air, water, food, or soil. The evidence of high $\mathrm{Pb}$ exposure warrants further investigation as to the primary mode of exposure in Vietnam battery recycling craft villages in the effort to reduce childhood exposures.

Among toenail levels, our analysis revealed statistically significant $(\mathrm{p}<0.05 ; \mathrm{r}>0.45)$ positive Spearman's correlations between $\mathrm{Mn}$ and $\mathrm{Cr}, \mathrm{Pb}$ and $\mathrm{Cd}, \mathrm{Mn}$ and $\mathrm{Cd}$, As and $\mathrm{Cd}$, and As and Mn. The two strongest relationships were observed between $\mathrm{Mn}$ and $\mathrm{Cr}(\mathrm{r}=0.72, \mathrm{p}<0.001)$ as well as $\mathrm{Pb}$ and $\mathrm{Cd}(\mathrm{r}=0.66, \mathrm{p}<0.05)$. Hg levels had weak associations with the other metal levels. In addition to smelting practices, several other sources of metals may contribute to co-exposure in the Nghia Lo community. For example, elevated levels of As and Mn have been found in drinking water sources in the Red River Delta [24,25,27]. A previous study found that $27 \%$ and $44 \%$ of groundwater wells exceeded the World Health Organization (WHO) guideline values for As $(10 \mu \mathrm{g} / \mathrm{L})$

Table 3 Spearman's correlation ( $r$ ) for toxic metal levels in children's toenails $(n=20)$ and blood $(n=17)$

\begin{tabular}{lcccccc}
\hline Metal $^{\mathbf{a}}$ & $\mathbf{C d}-\mathbf{N}$ & $\mathbf{C r}-\mathbf{N}$ & $\mathbf{P b}-\mathbf{N}$ & $\mathbf{M n}-\mathbf{N}$ & $\mathbf{H g}-\mathbf{N}$ & $\mathbf{P b}-\mathbf{B}$ \\
\hline As-N & $0.59^{*}$ & 0.07 & 0.42 & $0.58^{*}$ & -0.10 & 0.00 \\
Cd-N & & 0.26 & $0.66^{*}$ & $0.60^{*}$ & 0.03 & 0.04 \\
Cr-N & & & 0.02 & $0.72^{* *}$ & 0.26 & -0.43 \\
Pb-N & & & & 0.33 & 0.02 & $0.65^{*}$ \\
Mn-N & & & & & 0.01 & -0.30 \\
Hg-N & & & & & & -0.32 \\
\hline
\end{tabular}

${ }^{*} \mathrm{p}<0.05$.

** $p<0.001$.

${ }^{\mathrm{a}} \mathrm{B}$ denotes blood metal levels. $\mathrm{N}$ denotes toenail metal levels. 
and $\mathrm{Mn}(0.4 \mathrm{mg} / \mathrm{L})$, respectively $[24,47,48]$. Drinking water As levels in Vietnam range up to $3050 \mu \mathrm{g} / \mathrm{L}$ $[25,27]$, a level greater than 300 times the recommended WHO drinking water standard [47]. The biomonitored levels of As were lower in this group of children when compared to previous studies with high level As contamination; however, low-level and multi-metal exposure in childhood remains an important consideration for future health outcomes. The traditional Vietnamese diet also includes a high proportion of local seafood, which has been documented to contain methylmercury levels up to $0.5 \mu \mathrm{g} / \mathrm{g}[49,50]$. Compared with the United States EPA guideline of consumption of $0.1 \mu \mathrm{g} / \mathrm{kg}$ of methylmercury [51], dietary $\mathrm{Hg}$ represents a potential important alternate source of exposure. Other craft operations, including leather tanning, are documented sources of $\mathrm{Hg}$ and $\mathrm{Cr}$ exposure in craft villages [52-55]. For example, $\mathrm{Cr}$ salts used in tanning practices in Vietnam produce large amounts of solid and liquid toxic metal waste $[55,56]$. Although levels of As and $\mathrm{Cr}$ were relatively low in the toenail samples, multiple toxic metal biomarkers may be of interest in future studies to understand metal mixtures. The present study did not collect information on individual's diet, other craft operations in Nghia Lo, or measure toxic metals other than $\mathrm{Pb}$ in blood; these are relevant potential sources or biomarkers of metal exposure that should be considered in future studies.

\section{Distance to nearest active smelter and metal levels were associated}

Lastly, we examined the relationship between blood $\mathrm{Pb}$ and toenail metal levels to children's age, sex, and distance to the nearest active smelter using linear regression (Table 4). On average, males had a higher $\mathrm{Pb}$ level in both blood and toenails (BLL: $22.35 \mu \mathrm{g} / \mathrm{dL}, \mathrm{Pb}-\mathrm{N}$ : $86.8 \mathrm{ng} / \mathrm{g}$ ) than females (BLL: $20.8 \mu \mathrm{g} / \mathrm{dL}, \mathrm{Pb}-\mathrm{N}$ :
$54.3 \mathrm{ng} / \mathrm{g})$, but no statistically significant association was found between $\mathrm{Pb}$ level and sex. Similarly, no significant relationship with child's age was observed between blood $\mathrm{Pb}$ or any toenail metal levels. Our findings do not demonstrate a statistically significant association with child's age or sex. The lack of association with age may have been a result of unmeasured confounding due to the small sample size, or the relatively limited age range (1.5 to 4 years). Additional factors that affect metal body burden include child's body mass index, socioeconomic status, duration of residence, parental smoking status, and occupation. These covariates will aid in better characterizing the demographics of smelting craft village populations and should be considered in future studies.

The relationship between BLLs and the distance between a child's place of residence to the nearest active smelter showed a statistically significant $(\mathrm{p}<0.05)$ negative correlation. Specifically, a $50 \%$ reduction in the distance to the nearest active smelter was associated with a 2.16 fold-change or $116 \%$ increase in BLL. In fact, it is possible that due to our selection criteria these results may underestimate the relationship between distance and BLL. In addition, it is possible that children living farther from a smelter may have had parents who worked in $\mathrm{Pb}$ smelting, whereas children living closer to a smelter may have had parents who did not.

Toenail levels of $\mathrm{As}, \mathrm{Cd}$, and $\mathrm{Pb}$ were also negatively correlated with the distance to the nearest smelter, but were not found to be statistically significant. Especially relevant to the toenail biomarker, which is indicative of long-term exposure, it is important to note that there may have been historic exposure from the inactive smelter that was located closest to the village. The association between toenail levels of $\mathrm{Cr}$ and $\mathrm{Hg}$ and distance to the nearest active smelter showed statistically significant positive relationships for $\mathrm{Cr}$ and $\mathrm{Hg}(\mathrm{p}<0.05)$, meaning that children living farther away from $\mathrm{Pb}$

Table 4 Beta estimates (95\% confidence intervals) calculated from unadjusted linear regression analyses between toxic metal levels and distance to nearest active smelter, child's age, or sex

\begin{tabular}{|c|c|c|c|c|}
\hline \multirow[t]{2}{*}{ Metal $^{a}$} & \multicolumn{2}{|c|}{ Distance to nearest active smelter } & \multirow{2}{*}{$\begin{array}{c}\text { Age } \\
\beta(95 \% \mathrm{Cl})\end{array}$} & \multirow{2}{*}{$\begin{array}{c}\text { Sex }^{c} \\
\beta(95 \% \mathrm{Cl})\end{array}$} \\
\hline & $\beta(95 \% \mathrm{Cl})$ & Fold-change ( $\%$ change) $^{b}$ & & \\
\hline $\mathrm{Pb}-\mathrm{B}$ & $-1.11(-2.21,-0.01)^{*}$ & $2.16(116 \%)$ & $-0.17(-0.59,0.24)$ & $-0.14(-0.74,0.47)$ \\
\hline As-N & $-0.29(-1.47,0.89)$ & $1.22(22 \%)$ & $0.10(-0.30,0.51)$ & $-0.32(-0.90,0.26)$ \\
\hline $\mathrm{Cd}-\mathrm{N}$ & $-0.35(-1.34,0.64)$ & $1.28(28 \%)$ & $-0.08(-0.43,0.26)$ & $-0.39(-0.86,0.08)$ \\
\hline $\mathrm{Cr}-\mathrm{N}$ & $0.97(0.11,1.84)^{*}$ & $0.51(-49 \%)$ & $-0.05(-0.38,0.29)$ & $0.22(-0.26,0.70)$ \\
\hline $\mathrm{Pb}-\mathrm{N}$ & $-1.34(-3.65,0.96)$ & $2.54(154 \%)$ & $-0.07(-0.90,0.75)$ & $-0.43(-1.61,0.75)$ \\
\hline $\mathrm{Mn}-\mathrm{N}$ & $0.39(-0.75,1.53)$ & $0.76(-24 \%)$ & $-0.07(-0.47,0.33)$ & $-0.11(-0.69,0.46)$ \\
\hline $\mathrm{Hg}-\mathrm{N}$ & $2.39(0.80-3.98)^{*}$ & $0.19(-81 \%)$ & $0.04(-0.63,0.71)$ & $0.69(-0.23,1.61)$ \\
\hline
\end{tabular}

${ }^{*} \mathrm{p}<0.05$.

${ }^{\mathrm{a}} \mathrm{B}$ denotes blood metal levels. $\mathrm{N}$ denotes toenail metal levels.

${ }^{\mathrm{b}}$ Metal levels and the distance to the nearest active smelter were natural-log transformed. The fold-change values represent the exponentiated beta value $\left(0.5^{\beta}\right)$ and corresponding percent change in BLL when the distance to smelter is decreased by half.

${ }^{\mathrm{c}}$ Females served as the referent group. 
smelting operations had higher toenail levels of $\mathrm{Cr}$ and Hg. However, exclusion of the child with the furthest distance to smelter resulted in a negative, and nonstatistically significant relationship between distance to nearest smelter and nail levels of $\mathrm{Cr}$ and $\mathrm{Hg}$ (data not shown). These results may also be influenced by unmeasured confounding, and should be substantiated with a larger study sample.

\section{Conclusions}

Battery smelting craft practices in rural Vietnamese communities continue to increase in number due to the lucrative economic benefits. Data from this crosssectional pilot study indicate that children are not adequately protected from resultant toxic metal exposures. Overall, the findings show that children living in a battery recycling community had elevated levels of blood $\mathrm{Pb}$ and elevated levels of $\mathrm{Pb}, \mathrm{Hg}$, and $\mathrm{Mn}$ in toenail samples. Increased levels of $\mathrm{Pb}, \mathrm{Hg}$ and $\mathrm{Mn}$ are known to cause adverse neurodevelopmental outcomes in humans, and children are especially susceptible. In addition, we find that children are co-exposed to multiple other toxic metals including $\mathrm{As}, \mathrm{Cd}$, and $\mathrm{Cr}$, within the craft village setting. Metal exposure may arise directly as a result of smelting activities or other potential sources. This research emphasizes the need for both increased biomonitoring of metal exposure and public health strategies in these communities to alleviate children's exposure. Future studies to assess the adverse neurodevelopmental affects of multiple metal exposures among children living in smelting craft villages are needed.

\section{Abbreviations}

As: Arsenic; BLL: Blood lead level; Cd: Cadmium; Cr: Chromium; CDC: Centers for disease control and prevention; GPS: Global positioning system; Hg: Mercury; IQ: Intelligence quotient; LOD: Limit of detection; Mn: Manganese; NHANES IV: Fourth report on human exposure to environmental chemicals; Pb: Lead; WHO: World Health Organization.

\section{Competing interests}

The authors declare that they have no competing interests.

\section{Authors' contributions}

RCF and JBK conceived of and designed the study. VN collected the data. APS and SKM carried out the analyses. APS, SKM, and RCF wrote the manuscript. All authors read and approved the final manuscript.

\section{Acknowledgements}

We thank Quy Ngoc Bui in the Department of Cartography, University of Mining and Geology in Ha Noi and Dr. Dung Quang Trinh at the Vietnam National Hospital of Pediatrics for their assistance collecting geographic coordinate data and biological samples. We thank Frank Weber at the RTI International, Research Triangle Park, North Carolina for performing the metal analysis of toenail samples. This research was funded by grants from the NIEHS (T32-ES007018, P42-ES005948-18, P30-ES010126, and ES019315).

\section{Author details}

${ }^{1}$ Department of Environmental Sciences and Engineering, Gillings School of Global Public Health, University of North Carolina - Chapel Hill, Chapel Hill, North Carolina, USA. 'Department of Maternal and Child Health, Gillings School of Global Public Health, University of North Carolina - Chapel Hill,
Chapel Hill, North Carolina, USA. ${ }^{3}$ Curriculum in Toxicology, School of Medicine, University of North Carolina - Chapel Hill, Chapel Hill, North Carolina, USA. ${ }^{4}$ Lineberger Comprehensive Cancer Center, School of Medicine, University of North Carolina - Chapel Hill, Chapel Hill, North Carolina, USA.

Received: 2 October 2013 Accepted: 2 January 2014 Published: 4 February 2014

\section{References}

1. Grosse SD, Matte TD, Schwartz J, Jackson RJ: Economic gains resulting from the reduction in children's exposure to lead in the United States. Environ Health Perspect 2002, 110(6):563-569.

2. Landrigan PJ, Schechter CB, Lipton JM, Fahs MC, Schwartz J: Environmental pollutants and disease in American children: estimates of morbidity, mortality, and costs for lead poisoning, asthma, cancer, and developmental disabilities. Environ Health Perspect 2002, 110(7):721-728.

3. Bellinger D, Sloman J, Leviton A, Rabinowitz M, Needleman HL, Waternaux C: Low-level lead-exposure and childrens cognitive function in the preschool years. Pediatrics 1991, 87(2):219-227.

4. Hu H, Tellez-Rojo MM, Bellinger D, Smith D, Ettinger AS, Lamadrid-Figueroa H, Schwartz J, Schnaas L, Mercado-Garcia A, Hernandez-Avila M: Fetal lead exposure at each stage of pregnancy as a predictor of infant mental development. Environ Health Perspect 2006, 114(11):1730-1735.

5. Malcoe LH, Lynch RA, Keger MC, Skaggs VJ: Lead sources, behaviors, and socioeconomic factors in relation to blood lead of native american and white children: a community-based assessment of a former mining area. Environ Health Perspect 2002, 110(Suppl 2):221-231.

6. Ziegler EE, Edwards BB, Jensen RL, Mahaffey KR, Fomon SJ: Absorption and retention of lead by infants. Pediatr Res 1978, 12(1):29-34.

7. Lanphear BP, Roghmann KJ: Pathways of lead exposure in urban children. Environ Res 1997, 74(1):67-73.

8. Nriagu JO, Pacyna JM: Quantitative assessment of worldwide contamination of air, water and soils by trace metals. Nature 1988, 333(6169):134-139.

9. Okuda T, Katsuno M, Naoi D, Nakao S, Tanaka S, He K, Ma Y, Lei Y, Jia Y: Trends in hazardous trace metal concentrations in aerosols collected in Beijing, China from 2001 to 2006. Chemosphere 2008, 72(6):917-924.

10. Zheng XY, Pang LH, Wu JL, Pei LJ, Tan LF, Yang C, Song XM: Contents of heavy metals in arable soils and birth defect risks in Shanxi, China: a small area level geographic study. Popul Environ 2012, 33(2-3):259-268,

11. Helmfrid I, Berglund M, Lofman O, Wingren G: Health effects and exposure to polychlorinated biphenyls (PCBs) and metals in a contaminated community. Environ Int 2012, 44:53-58.

12. Diaz-Barriga F, Santos MA, Mejia JJ, Batres L, Yanez L, Carrizales L, Vera E, del Razo LM, Cebrian ME: Arsenic and cadmium exposure in children living near a smelter complex in San Luis Potosi, Mexico. Environ Res 1993, 62(2):242-250.

13. Wright RO, Amarasiriwardena C, Woolf $A D$, Jim R, Bellinger DC: Neuropsychological correlates of hair arsenic, manganese, and cadmium levels in school-age children residing near a hazardous waste site. Neurotoxicology 2006, 27(2):210-216

14. Lidsky TI, Schneider JS: Lead neurotoxicity in children: basic mechanisms and clinical correlates. Brain 2003, 126:5-19.

15. Wasserman GA, Liu XH, Factor-Litvak P, Gardner JM, Graziano JH: Developmental impacts of heavy metals and undernutrition. Basic Clin Pharmacol 2008, 102(2):212-217.

16. Mahaffey KR, Capar SG, Gladen BC, Fowler BA: Concurrent Exposure to Lead, Cadmium, and Arsenic - Effects on Toxicity and Tissue Metal Concentrations in the Rat. J Lab Clin Med 1981, 98(4):463-481.

17. Pecze L, Papp A, Nagymajtenyi L, Desi I: Effect of acute administration of certain heavy metals and their combinations on the spontaneous and evoked cortical activity in rats. Environ Toxicol Pharmacol 2005, 19(3):775-784.

18. Vellinger C, Parant M, Rousselle P, Usseglio-Polatera P: Antagonistic toxicity of arsenate and cadmium in a freshwater amphipod (Gammarus pulex). Ecotoxicology 2012, 21(7):1817-1827.

19. Byzitter J, Lukowiak K, Karnik V, Dalesman S: Acute combined exposure to heavy metals $(\mathrm{Zn}, \mathrm{Cd})$ blocks memory formation in a freshwater snail. Ecotoxicology 2012, 21(3):860-868. 
20. Fowler BA, Whittaker MH, Lipsky M, Wang GS, Chen XQ: Oxidative stress induced by lead, cadmium and arsenic mixtures: 30-day, 90-day, and 180-day drinking water studies in rats: an overview. Biometals 2004, 17(5):567-568.

21. Office GS: Statistical Handbook of Vietnam 2012. Hanoi, Vietnam: Statistical Publishing House; 2012.

22. Van Ha N, Kant S, Madaren V: Shadow prices of environmental outputs and production efficiency of household-level paper recycling units in Vietnam. Ecol Econ 2008, 65(1):98-110.

23. Ngoc MN, Dultz S, Kasbohm J: Simulation of retention and transport of copper, lead and zinc in a paddy soil of the Red River Delta, Vietnam. Agr Ecosyst Environ 2009, 129(1-3):8-16.

24. Winkel LHE, Pham TKT, Vi ML, Stengel C, Amini M, Nguyen TH, Pham HV, Berg M: Arsenic pollution of groundwater in Vietnam exacerbated by deep aquifer exploitation for more than a century. Proc Natl Acad Sci USA 2011, 108(4):1246-1251.

25. Berg M, Stengel C, Pham TK, Pham HV, Sampson ML, Leng M, Samreth S, Fredericks D: Magnitude of arsenic pollution in the Mekong and Red River Deltas-Cambodia and Vietnam. Sci Total Environ 2007, 372(2-3):413-425.

26. Eiche E, Neumann T, Berg M, Weinman B, van Geen A, Norra S, Berner Z, Trang PTK, Viet PH, Stuben D: Geochemical processes underlying a sharp contrast in groundwater arsenic concentrations in a village on the Red River delta, Vietnam. App/ Geochem 2008, 23(11):3143-3154.

27. Berg M, Tran HC, Nguyen TC, Pham HV, Schertenleib R, Giger W: Arsenic contamination of groundwater and drinking water in Vietnam: A human health threat. Environ Sci Technol 2001, 35(13):2621-2626.

28. Haefliger P, Mathieu-Nolf M, Lociciro S, Ndiaye C, Coly M, Diouf A, Faye AL, Sow A, Tempowski J, Pronczuk J, et al: Mass lead intoxication from informal used lead-acid battery recycling in Dakar, Senegal. Environ Health Perspect 2009, 117(10):1535-1540.

29. Hurtado CM: Clinical aspects and lead levels in children exposed to paraocupational automobile battery recycling process in the locations of Soacha and Bogotá D.C. Biomedica 2008, 28(1):2-30.

30. CDC: In Blood Lead Levels in Children: What do Parents Need to Know to Protect Their Children. Edited by Health NCfE. Atlanta, GA: Center for Disease Control and Prevention; 2012.

31. CDC: Managing Elevated Blood Lead Levels Among Young Children: Recommendations from the Advisory Committee on Childhood Lead Poisoning Prevention. Atlanta, GA: CDC; 2002.

32. CDC: Fourth Report on Human Exposure to Environmental Chemicals, Updated Tables. Atlanta, GA: US Department of Health and Human Services; 2013.

33. Al-Saleh I, Al-Sedairi A: Mercury $(\mathrm{Hg})$ burden in children: the impact of dental amalgam. Sci Total Environ 2011, 409(16):3003-3015.

34. Xun P, Liu K, Morris JS, Jordan JM, He K: Distributions and determinants of mercury concentrations in toenails among American young adults: the CARDIA Trace Element Study. Environ Sci Pollut Res Int 2013, 20(3):1423-1430

35. Gibb H, Haver C, Kozlov K, Centeno JA, Jurgenson V, Kolker A, Conko KM Landa ER, Xu H: Biomarkers of mercury exposure in two eastern Ukraine cities. J Occup Environ Hyg 2011, 8(4):187-193.

36. Were FHN, Wilson M, Murungi J, Wanjau R: Comparison of some essential and heavy metals in the toenails and fingernails of school-age children in Kenya. Bull Chem Soc Ethiop 2009, 23(1):117-122.

37. Wilhelm M, Hafner D, Lombeck I, Ohncsorge FK: Monitoring of cadmium, copper, lead and zinc status in young children using toenails: comparison with scalp hair. Sci Total Environ 1990, 103(1991):199-207.

38. Slotnick MJ, Nriagu JO, Johnson MM, Linder AM, Savoie KL, Jamil HJ, Hammad AS: Profiles of trace elements in toenails of Arab-Americans in the Detroit area, Michigan. Biol Trace Elem Res 2005, 107(2):113-126.

39. Wasserman GA, Liu XH, Parvez F, Ahsan H, Levy D, Factor-Litvak P, Kline J, van Geen A, Slavkovich V, Lolacono NJ, et al: Water manganese exposure and children's intellectual function in Araihazar, Bangladesh. Environ Health Perspect 2006, 114(1):124-129.

40. Counter SA, Buchanan LH: Mercury exposure in children: a review. Toxicol Appl Pharmacol 2004, 198(2):209-230

41. Pearce DC, Dowling K, Gerson AR, Sim MR, Sutton SR, Newville M, Russell R, McOrist G: Arsenic microdistribution and speciation in toenail clippings of children living in a historic gold mining area. Sci Total Environ 2010, 408(12):2590-2599.
42. Parvez FW, Gail A, Factor-Litvak P, Liu X, Slavkonich V, Siddique AB, Sultana R, Islam T, Levy D, Mey JL, van Green A, Khan K, Kline J, Ahsan H, Graziano $\mathrm{JH}$ : Arsenic exposure and motor function among children in Bangladesh. Environ Health Perspect 2011, 119(11):1665-1670.

43. Pocock SJS, Smith M, Baghurst P: Environmental lead and children's intelligence: a systematic review of the epidemiological evidence. BMJ 1994, 309(6963):1189-1197.

44. Kim Y, Ha EH, Park H, Ha M, Kim Y, Hong YC, Kim EJ, Kim BN: Prenatal lead and cadmium co-exposure and infant neurodevelopment at 6 months of age: the Mothers and Children's Environmental Health (MOCEH) study. Neurotoxicology 2013, 35:15-22

45. He K: Trace elements in nails as biomarkers in clinical research. Eur J Clin Invest 2011, 41(1):98-102

46. Barbosa F, Tanus-Santos JE, Gerlach RF, Parsons PJ: A critical review of biomarkers used for monitoring human exposure to lead: Advantages, limitations, and future needs. Environ Health Perspect 2005 113(12):1669-1674.

47. WHO, Cotruvo J, Fawell JK, Giddings M, Jackson P, Magara Y, Ngowi AVF, Ohanian E: Arsenic in Drinking-water: WHO Guidelines for Drinking-water Quality. Geneva, Switzerland: World Health Organization (WHO) Press; 2011.

48. WHO, Cotruvo J, Fawell JK, Giddings M, Jackson P, Magara Y, Ngowi AVF, Ohanian E: Manganese in Drinking-water: Background document for development of WHO Guidelines for Drinking-water Quality. Geneva, Switzerland: World Health Organization (WHO) Press; 2011.

49. Nghia ND, Lunestad BT, Trung TS, Son NT, Maage A: Heavy metals in the farming environment and in some selected aquaculture species in the Van Phong Bay and Nha Trang Bay of the Khanh Hoa Province in Vietnam. Bull Environ Contam Toxicol 2009, 82(1):75-79.

50. Le DQ, Duc CN, Harino H, Kakutani N, Chino N, Arai T: Distribution of trace metals and methylmercury in soft tissues of the freshwater Eel Anguilla marmorata in Vietnam. Arch Environ Con Toxicol 2010, 59(2):282-290.

51. Methylmercury (MeHg); CASRN 22967-92-6. Agency EP; 2001. http://www.epa.gov/iris/subst/0073.htm.

52. United States Environmental Protection Agency: Mercury Update: Impact on Fish Advisories. Office of Water. Washington D.C: United States Environmental Protection Agency (US EPA); 2001

53. Grevatt PC: Toxicological Review of Hexavalent Chromium. Washington, D.C: United States Environmental Protection Agency (US EPA); 1998.

54. Grevatt PC: Toxicological Review of Trivalent Chromium. Washington, D.C: United States Environmental Protection Agency (US EPA); 1998.

55. Mahanty S, Dang TD: Crafting Sustainability? The Potential and Limits of Institutional Design in Managing Water Pollution from Vietnam's Craft Villages. Soc Nat Resour 2013, 26(6):717-732.

56. Alexander KTW, Corning DR, Cory NJ, Donohue VJ, Sykes RL: Environmental and safety issues - clean technology and environmental auditing. J Soc Leath Tech Ch 1992, 76(1):17-23.

doi:10.1186/1471-2458-14-114

Cite this article as: Sanders et al:: Toxic metal levels in children residing in a smelting craft village in Vietnam: a pilot biomonitoring study. BMC Public Health 2014 14:114.

\section{Submit your next manuscript to BioMed Central and take full advantage of:}

- Convenient online submission

- Thorough peer review

- No space constraints or color figure charges

- Immediate publication on acceptance

- Inclusion in PubMed, CAS, Scopus and Google Scholar

- Research which is freely available for redistribution 